\title{
Teaching NeuroImages: Nonketotic hyperglycemic hyperosmolar state mimicking acute ischemic stroke
}

Marta I. Bala, MD, Anibal Chertcoff, MD, Miguel Saucedo, MD, Fabio Gonzalez, MD, Luis A. Miquelini, MD, Pablo Bonardo, MD, and Ricardo Reisin, MD

Neurology ${ }^{\circledR}$ 2020;95:e2600-e2601. doi:10.1212/WNL.0000000000010649

Figure Occipital MRI changes in nonketotic hyperglycemic hyperosmolar state

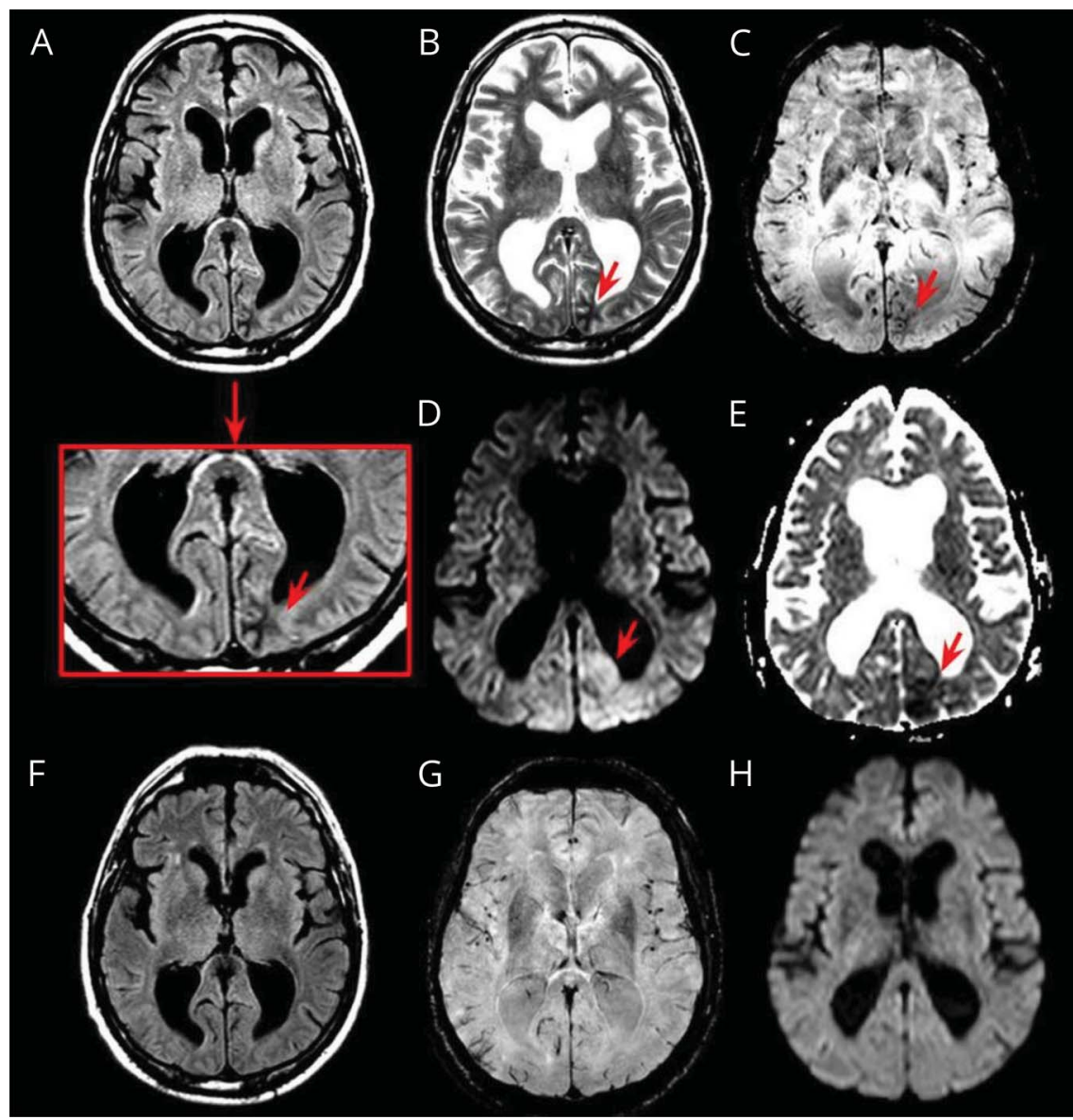

On admission, brain MRI showed a left subcortical occipital lesion that was hypointense on fluid-attenuated inversion recovery, $\mathrm{T} 2$, susceptibility-weighted imaging, and apparent diffusion coefficient map ( $\mathrm{A}-\mathrm{C}$ and $\mathrm{E}$ ) and hyperintense on diffusion-weighted imaging (D). A control brain MRI performed at 3 months was normal (F-H).

A 55-year-old man with diabetes mellitus type 2 presented with persistent right homonymous hemianopia of 72 hours evolution. At admission, the laboratory examination revealed blood glucose of $497 \mathrm{mg} / \mathrm{dL}$ and hyperosmolality without ketosis; the EEG did not show epileptic discharges. EEG done during the following days did not show any abnormalities. Brain MRI

\section{Correspondence}

Dr. Bala

martainesbb@gmail.com

\section{MORE ONLINE}

$\rightarrow$ Teaching slides

links.lww.com/WNL/

B190

From the Departments of Neurology (M.I.B., A.C., M.S., F.G., P.B., R.R.) and Neuroradiology (L.A.M.), Hospital Británico de Buenos Aires, Argentina.

Go to Neurology.org/N for full disclosures. Funding information and disclosures deemed relevant by the authors, if any, are provided at the end of the article. 
showed a subcortical lesion on the left occipital lobe (figure). The patient's symptoms and MRI abnormalities resolved after glucose-lowering treatment.

Nonketotic hyperglycemic hyperosmolar state is a condition associated with neurologic deficits that could mimic an acute ischemic stroke. The underlying mechanisms for MRI findings in this condition have not been fully elucidated, but it has been postulated that increased plasma osmolality with the subsequent development of hyperviscosity may lead to a hypoxic-ischemic insult resulting in the release of free radicals in the brain. ${ }^{1,2}$

\section{Study funding}

No targeted funding reported.

\section{Disclosure}

The authors report no disclosures relevant to the manuscript. Go to Neurology.org/N for full disclosures.

\section{Appendix Authors}

\begin{tabular}{lll}
\hline Name & Location & Contribution \\
\hline Marta I. & Hospital Britanico, & $\begin{array}{l}\text { Study concept and design, drafting } \\
\text { of the manuscript, critical revision } \\
\text { Bala, MD }\end{array}$ \\
& $\begin{array}{l}\text { Buenos Aires, } \\
\text { Argentina }\end{array}$ &
\end{tabular}

Appendix (continued)

\begin{tabular}{lll}
\hline Name & Location & Contribution \\
\hline $\begin{array}{l}\text { Anibal } \\
\text { Chertcoff, } \\
\text { MD }\end{array}$ & $\begin{array}{l}\text { Hospital Britanico, } \\
\text { Buenos Aires, } \\
\text { Argentina }\end{array}$ & $\begin{array}{l}\text { Drafting of the manuscript, critical } \\
\text { revision of the manuscript }\end{array}$ \\
\hline $\begin{array}{l}\text { Miguel } \\
\text { Saucedo, } \\
\text { MD }\end{array}$ & $\begin{array}{l}\text { Hospital Britanico, } \\
\text { Buenos Aires, }\end{array}$ & $\begin{array}{l}\text { Drafting of the manuscript, critical } \\
\text { revision of the manuscript }\end{array}$ \\
\hline $\begin{array}{l}\text { Fabio } \\
\text { Gonzalez, } \\
\text { MD }\end{array}$ & $\begin{array}{l}\text { Hospital Britanico, } \\
\text { Argenos Aires, }\end{array}$ & $\begin{array}{l}\text { Drafting of the manuscript, critical } \\
\text { revision of the manuscript }\end{array}$ \\
\hline $\begin{array}{l}\text { Luis A. } \\
\text { Miquelini, } \\
\text { MD }\end{array}$ & $\begin{array}{l}\text { Hospital Britanico, } \\
\text { Buenos Aires, }\end{array}$ & $\begin{array}{l}\text { Drafting of the manuscript, critical } \\
\text { revision of the manuscript }\end{array}$ \\
\hline $\begin{array}{l}\text { Pablo } \\
\text { Bonardo, } \\
\text { MD }\end{array}$ & $\begin{array}{l}\text { Hospital Britanico, } \\
\text { Buenos Aires, }\end{array}$ & $\begin{array}{l}\text { Drafting of the manuscript, critical } \\
\text { revision of the manuscript }\end{array}$ \\
\hline $\begin{array}{l}\text { Ricardo } \\
\text { Reisin, MD }\end{array}$ & $\begin{array}{l}\text { Hospital Britanico, } \\
\text { Buenos Aires, }\end{array}$ & $\begin{array}{l}\text { Drafting of the manuscript, critical } \\
\text { revision of the manuscript }\end{array}$ \\
\hline
\end{tabular}

\section{References}

1. Raghavendra S, Ashalatha R, Thomas SV, Kesavadas C. Focal neuronal loss, reversible subcortical focal T2 hypointensity in seizures with a nonketotic hyperglycemic hyperosmolar state. Neuroradiology 2007;49:299-305.

2. Strowd RE, Wabnitz A, Balakrishnan N, Craig J, Tegeler $\mathrm{CH}$. Clinical reasoning: acute-onset homonymous hemianopia with hyperglycemia. Neurology 2014;82: e129-e133. 


\section{Neurology}

\section{Teaching NeuroImages: Nonketotic hyperglycemic hyperosmolar state mimicking acute ischemic stroke}

Marta I. Bala, Anibal Chertcoff, Miguel Saucedo, et al.

Neurology 2020;95;e2600-e2601 Published Online before print August 14, 2020

DOI 10.1212/WNL.0000000000010649

This information is current as of August 14, 2020

Updated Information \&

Services

References

Subspecialty Collections

Permissions \& Licensing

Reprints including high resolution figures, can be found at: http://n.neurology.org/content/95/18/e2600.full

This article cites 2 articles, 1 of which you can access for free at: http://n.neurology.org/content/95/18/e2600.full\#ref-list-1

This article, along with others on similar topics, appears in the following collection(s):

\section{All Cerebrovascular disease/Stroke}

http://n.neurology.org/cgi/collection/all_cerebrovascular_disease_strok

Clinical neurology history

http://n.neurology.org/cgi/collection/clinical_neurology_history

Endocrine

http://n.neurology.org/cgi/collection/endocrine

Infarction

http://n.neurology.org/cgi/collection/infarction

Visual loss

http://n.neurology.org/cgi/collection/visual_loss

Information about reproducing this article in parts (figures,tables) or in its entirety can be found online at:

http://www.neurology.org/about/about_the_journal\#permissions

Information about ordering reprints can be found online:

http://n.neurology.org/subscribers/advertise

Neurology ${ }^{\circledR}$ is the official journal of the American Academy of Neurology. Published continuously since 1951, it is now a weekly with 48 issues per year. Copyright (C 2020 American Academy of Neurology. All rights reserved. Print ISSN: 0028-3878. Online ISSN: 1526-632X.

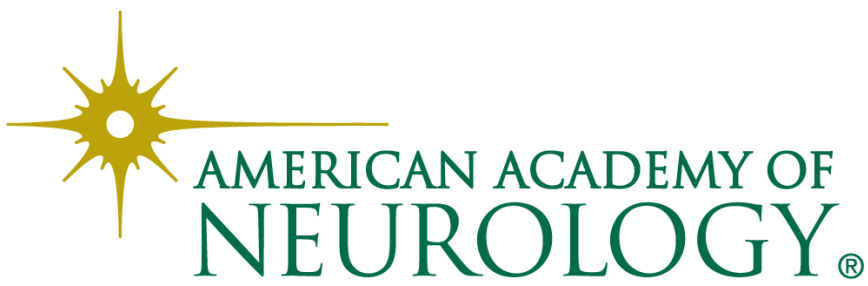

